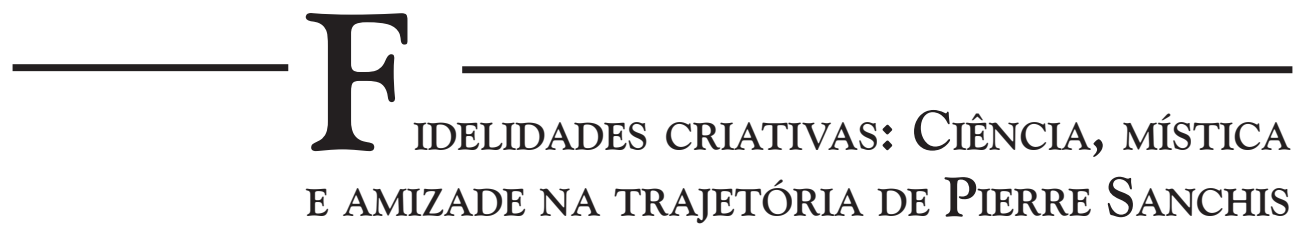

Carlos Alberto Steil

Cabe-me tecer, aqui, algumas considerações sobre a trajetória pessoal e intelectual de um destacado antropólogo franco-brasileiro que, aos 89 anos, no dia 7 de maio de 2018, deixou o convívio dos familiares e amigos, interrompido por sua morte. Vamos falar de Pierre Sanchis, com quem tive a alegria de partilhar a amizade por um longo tempo, desde os anos 1980, quando, no Instituto de Estudos da Religião (ISER), no Rio de Janeiro, frequentava o Grupo de Estudos do Catolicismo, que ele coordenava. Além de amigo, Pierre foi um mestre que, juntamente com outros cientistas sociais que fizeram do ISER sua casa - entre os quais destaco Otávio Velho, Ruben Fernandes, Carlos Rodrigues Brandão, Regina Novaes, Patrícia Birman, Ralph Della Cava, Pedro Ribeiro de Oliveira e Cecília Mariz -, marcou meu percurso acadêmico, quando começava a delinear-se minha escolha pela antropologia. Um início que não poderia ter sido mais instigante, na medida em que o ISER nos proporcionava um diálogo interdisciplinar produtivo, reunindo em seu espaço um grande número de cientistas sociais, teólogos, educadores e historiadores que o transformaram num importante lócus de produção de conhecimento sobre a religião no Brasil e uma referência para muito além de seus muros. Há que se destacar, ainda, suas revistas Religião Eु Sociedade e Comunicações do ISER que, assim como um grande número de outras publicações em livros, coletâneas e vídeos, vieram a lume com a chancela do ISER. Nesse trabalho, Pierre foi um incansável batalhador e uma liderança inconteste ${ }^{1}$.

Um outro lugar que me aproximou de Pierre foi a Associação de Cientistas Sociais da Religião do Mercosul (ACSRM). Fundada em 1991, a ACSRM tem como missão aproximar cientistas sociais da religião, inicialmente dos países do Cone Sul 
e, depois, de toda a América Latina, com o objetivo de promover a produção da área na região e facilitar as parcerias de pesquisa entre seus associados. Neste sentido, tem papel preponderante as Jornadas sobre Alternativas Religiosas, realizadas a cada dois anos, na Argentina, no Brasil, no Chile e no Uruguai, alternadamente. Como associado, desde sua criação, Pierre destacou-se por sua contribuição inequívoca aos estudos do tema. A originalidade e a força de seu pensamento tiveram grande influência sobre os cientistas sociais dos outros países, abrindo caminhos para a realização de pesquisas comparadas entre contextos nacionais. $\mathrm{O}$ reconhecimento da contribuição do seu pensamento para a América Latina foi expresso nas XII Jornadas sobre Alternativas Religiosas, que se realizaram em São Paulo, em 2005, por meio de uma mesa-redonda em sua homenagem com a presença de cientistas sociais do Brasil e da Argentina que discutiram alguns aspectos centrais de seu pensamento (Mariz 2005; Semán 2005; Perez e Santos 2005; Frigerio 2005)².

Essa homenagem a Pierre, realizada pela Associação de Cientistas Sociais da Religião do Mercosul, foi antecedida por uma outra homenagem, organizada no âmbito da Universidade Federal de Minas Gerais (UFMG), por ocasião da outorga do título de Professor Emérito, em junho de 1999. No decorrer de três dias, debatemos a sua contribuição aos estudos da religião. As exposições apresentadas nas diversas mesas-redondas do encontro foram publicadas num número especial da revista Teoria e Sociedade, que saiu em maio de 2003. Tive a grata satisfação de estar presente nas duas homenagens e ouvir não apenas os colegas, que discorreram sobre o pensamento de Pierre, mas, também, a sua conferência de abertura do encontro de Belo Horizonte, que ele intitulou de "A religião dos brasileiros" (Sanchis 2003a), e sua fala final, "A graça e a gratidão" (Sanchis 2003b), na qual relata, num tom muito pessoal, sua trajetória, desde menino, na França, até aquele momento, em que festejava, com familiares, amigos, colegas e estudantes, o coroamento de um percurso intelectual, reconhecido por sua universidade.

Ao imaginar um modo de falar de Pierre e de expressar meu tributo à sua presença indelével na vida e trajetória de tantos colegas que, como eu, beberam de sua fonte inexaurível, muitas possibilidades se apresentaram. Entre elas, no entanto, escolhi aquela que me pareceu, de imediato, capaz de conectar-me com o que ele pessoalmente expressou em termos dos seus sentimentos e de suas linhas de pensamento. Foi, assim, que surgiu a ideia de seguir e comentar sua fala "A graça e a gratidão", na qual ele entrelaça, com sentimento e paixão, os fios de sua vida pessoal com os de sua trajetória intelectual. Dimensões estas - vida e pensamento - que, como sabem aqueles que conviveram com Pierre, estiveram sempre imbricadas no seu percurso como ser humano e como intelectual. Seu modo de habitar o mundo sempre foi, também, seu modo de conhecê-lo. Espero ter conseguido, nesta desafiadora tarefa que me impus, transpor para o texto que apresento e compartilho com o leitor um pouco da graça e da gratidão que foi para todos nós, seus amigos, ter conhecido e partilhado de sua vida. 


\section{Infância: França}

Pierre teve uma vida longa e plena de realizações, ainda que sempre inquieto diante dos muitos desafios a que se impunha. Registrado com o nome de Joseph-François-Pierre Sanchis, ele nasceu em Perpignan, França, em 16 de dezembro de 1928. A releitura de sua infância, expressa na maturidade de seus 70 anos, entrelaça os fios da vida com os do pensamento, numa trama tal que já não é possível desfazer o denso tecido que resultou de sua experiência humana. Perguntado por seus alunos: "Afinal por que você foi ser antropólogo", sua resposta espontânea e direta foi: "Porque sou catalão!" (Sanchis 2003b:162). Enfim, tratava-se de ir à raiz de uma vocação profissional que teve como solo primeiro a intensa experiência pessoal de sua infância, marcada por uma dupla identidade, que se inscreve nas fronteiras da nação francesa, mas que a ultrapassa, na medida em que o remete para a cultura catalã, presente nos dois lados dos Pirineus, dividida por um tratado entre nações, fazendo de uns franceses e outros espanhóis. Citando Pierre:

Para tornar mais complexo o equacionamento desta charada, [cresci] numa família que, por um lado, referia-se de perto à Espanha, por outro, enraizava-se muito fundo nos séculos da história do Roussillon (pois é assim que se chama a parte francesa da Catalunha), a socialização ambiente, a transmissão cultural explícita, sobretudo na escola, levavam-me a me reconhecer francês. E também, a gostar de sê-lo (Sanchis 2003b:162).

É, portanto, essa experiência, vivida na carne e na história, que o conduz, depois de um longo caminho, à antropologia. Suas palavras para descrever sua infância estão carregadas de vida e cor. Elas expõem, à flor da pele, os sentimentos mais profundos e amorosos para com o lugar de sua origem. "Uma terrinha à beira do Mediterrâneo, muito variegada nas suas paisagens, seus climas, seus costumes, mas que sempre me pareceu dotada de uma consciência de identidade própria, identidade que sua história lhe fazia compartilhar com a terra de outros catalães [...]". (Sanchis 2003b:162).

Esta dupla identidade atravessa e estrutura seu olhar e sua sensibilidade, preparando-o, desde muito cedo, para lidar com as diferenças que o constituem como indivíduo, assim como para compreender a diversidade das culturas que, na sua experiência pessoal, transbordam as fronteiras de um território ou Estado nacionais. Culturas diferenciadas que se expressam em diferentes dimensões da vida social e que vão lançar mão de recursos e agenciamentos próprios para produzir pertencimentos. Caminhos que se bifurcam no mapa racional das escolhas possíveis, mas que, por força da dialética vivida, acabam, pelo menos no caso de Pierre, por convergir, mais à frente, e em diferentes momentos, para sínteses e arranjos, sempre provisórios, que 
conferem sentido aos caminhos trilhados. Este movimento contínuo entre mundos diversos, operado pela lógica dialética do encontro com o "outro", acompanha toda a trajetória de Pierre. E, nesta, ele vai agregando novos sujeitos, novos grupos sociais e religiosos, novas instituições e novas culturas, num esforço reiterado de compreender os processos sociais. Tal experiência confere-lhe o pano de fundo que conforma a sua aguda percepção da tensão fundante entre o popular e o erudito, entre o movimento e a instituição, presentes na dinâmica social. Como ele mesmo diz:

Uma cultura "oficial" sistematicamente aprendida e, sem dúvida, introjetada, outra cultura apreendida em contatos mais sutis, poesia e festas, música e excursões a lugares históricos, mergulhos em redutos camponeses, nichos ainda conservados da língua catalã: esses dois níveis existencialmente distintos de um mesmo fenômeno, a "cultura", desafiam desde a infância o meu entendimento, e diziam respeito a meu jeito de me definir: identidade? (Sanchis 2003b:162).

É na infância que Pierre localiza outra vertente da sua vocação de antropólogo: a viagem em busca do "outro", que vive em terras distantes. Visto, de longe, na imaginação da criança, como o exótico, o primitivo, o desconhecido. Uma viagem que ele empreendeu primeiramente nas páginas dos livros infantis e da adolescência que ele lia com grande interesse e admiração. Ao referir-se a essa etapa da existência, sua memória o conduz às suas noites de insônia, quando, ainda criança, encontrava, na leitura dos volumes encadernados em couro vermelho de uma revista: Lectures pour tous, os quadros de viagens e explorações, material indispensável, segundo ele, para que sua imaginação pudesse transpor os limites da Europa civilizada em direção ao novo mundo (Sanchis 2003b:162).

\section{Chegadas e partidas: Brasil, Portugal, França, Brasil}

O sonho da viagem ao encontro do "outro" e o fascínio pela diferença do menino realizar-se-iam na juventude, quando decide migrar para o Brasil. Neste ponto, é preciso lembrar que essa decisão se configurava no contexto do seu pertencimento a uma ordem religiosa. A vocação missionária, vivida por ele como uma sedução avassaladora, concretiza-se por meio de sua transferência para o Brasil que o conduz primeiramente para a "serra do mar paranaense, depois para o Rio de Janeiro, quando fiz a experiência de uma consciente transmutação cultural" (Sanchis 2003b:162-163). Duas vocações articulam-se, nestes seus primeiros anos no Brasil: a missionária e a antropológica ${ }^{3}$. Esta divisão atravessa sua vida como uma tensão estrutural que opera a partir de dois regimes diferentes de aproximação com a religião. Ou seja, a primeira situada no espaço da mística e da fé, e a segunda no da razão e do conhecimento científico. Em ambas, no entanto, revela-se um desconforto pessoal em relação ao 
passado e um desejo difuso que o impele a estabelecer uma ruptura com o Velho Mundo. Condição, vista por ele, naquele momento, como indispensável para realizar uma imersão na cultura brasileira. Ou, como ele dirá, um esforço sincero de aderir ao modo de ser brasileiro.

Este movimento de repúdio a sua cultura anterior, porém, será revisto, mais tarde, depois de um período de retorno à França, para completar sua formação como antropólogo. Suas palavras sobre este processo de ruptura e reatamento, vivido de forma agonística e profunda em sua viagem de volta, são contundentes:

Quanto a mim, foi na França que os cordões do meu pacote problemático se ataram, ao preço de nova complexificação. Pois essa reinserção na cultura francesa me levou a recuperar, vinda do profundo de minhas entranhas, onde eu havia tido a ilusão de enclausurá-la, essa parte de minha identidade. Sem, dessa vez, me induzir - longe disso - a recalcar a face brasileira que me havia dado (Sanchis 2003b:163).

Seu retorno temporário à França passou por Portugal, que acrescentou um novo elemento identitário à complexidade do sincretismo que Pierre desvendava no Brasil. Às articulações entre catolicismo, religiões de matriz africana e indígenas, somavam-se, agora, a descoberta de um catolicismo lusitano, forjado no encontro histórico entre culturas pré-célticas, célticas e romanas em solo português, como sedimentações populares da cultura portuguesa. Visto em perspectiva, ele reconhecerá que se trata de um catolicismo historicamente diverso daquele que se configurou em solo brasileiro com a colonização. Essa descoberta, por sua vez, acaba por desvendar uma outra camada, instituinte do catolicismo brasileiro, diferente daquela, de coloração afro, que ele havia pesquisado, a partir da celebração, na Bahia, da Missa do Morro, para sua dissertação de mestrado. Ou seja, à descoberta da presença afro na liturgia católica (Sanchis 2003b:164), como um marcador do sincretismo na cultura católico -brasileira, vão se somar as suas raízes ibero-portuguesas, das festas e romarias. Assim, seguindo as linhas que tecem o catolicismo brasileiro, ele empreende a pesquisa, para sua tese de doutorado, junto aos aldeões do interior de Portugal.

Enfim, suas buscas teóricas se dão também nos espaços físicos por meio de seus deslocamentos entre o Velho e o Novo Mundo. Um movimento que reitera aquilo que será constante em seu pensamento: a articulação das diferenças. Como ele mesmo afirma: "Mais uma vez: isto ou aquilo? Um Brasil afro ou português? Levei um certo tempo para entender que a resposta exigia, também ela, não um meio termo ou uma mistura, mas uma articulação" (Sanchis 2003b:164). E, certamente, será esta maneira de lidar com as diferenças, aprendida nessas idas e vindas, que o tornam, ao mesmo tempo e sem confusão, francês, catalão e brasileiro. $\mathrm{Ou}$, para ser mais específico, como ele afirma, "mais tarde também alguns colegas, brincando, me decretarão 'mais mineiro do que os mineiros"” (Sanchis 2003b:164). Uma identida- 
de que, no mais genuíno estilo de Pierre, será incorporada positivamente como um traço de sua personalidade, redefinindo o estereótipo: "mineiro não como aquele que fica passivamente em cima do muro, mas aquele que sempre soube criativamente articular retaguarda com ousadia, tradição com modernidade, referência à terra com universalidade" (Sanchis 2003b:164). Talvez, aqui, ele acrescentaria à resposta dada aos alunos: antropólogo porque mineiro.

\section{Família, amigos e mestres}

A viagem de volta ao Velho Mundo foi empreendida como um projeto familiar. Como Pierre nos conta, as circunstâncias políticas de censura e perseguições, dos anos 1970, impostas pelo Golpe Militar de 1964, "levaram-nos, Maria de Lourdes e eu, a optar por uma formação fora do Brasil e, sobretudo, nos proibiram de voltar a ele tão cedo quanto o desejávamos" (Sanchis 2003b:163). Levaram consigo um filho, Rémy, e voltaram com dois, visto que Isabelle nasceu no período em que viveram na Europa. Em sua fala, no encerramento do evento de Belo Horizonte, suas palavras de gratidão para Maria de Lourdes e para os filhos, a quem nomeia de "meus professores", são carregadas de afeto e de amor, ditas com a delicadeza que lhe era peculiar.

Olhando para estes anos aqui evocados e pensando em como se escreveram e em como se inscreveram na pequena história de meu universo pessoal, como não agradecer ainda, e antes de todos, àquela sem quem nem anos, nem representações, nem dias teriam sido, de mil maneiras, possíveis, Maria de Lourdes. Se houve construção, ela é nossa. E não esqueço a parte que nela tomaram - e tomam - meus filhos Rémy e Isabelle (Sanchis 2003b:162).

Este amor familial estende-se e transborda para os amigos que Pierre foi fazendo ao longo de sua vida. Amizades moduladas por múltiplos encontros: geracional, trabalho, orientandos, estudantes, além daquelas, de mais longa duração, que não se dissolveram nem mesmo quando os laços institucionais com a ordem se romperam. Aqui, posso falar das modulações que me tocaram viver. A primeira conduz-me às décadas de 1980-1990, quando pude acompanhar, na condição de aprendiz de antropologia, os encontros e as reuniões no ISER, do Grupo de Estudos do Catolicismo, que reunia parte importante da primeira geração de intelectuais do instituto ${ }^{4}$. Mestres inspiradores para a minha geração e para tantas outras que se seguiram, trilhando os caminhos por eles abertos, ao mesmo tempo que buscávamos divisar outros horizontes. Observávamos, com certo fascínio, o altíssimo rigor conceitual de que se revestiam os conceitos, as categorias, a partilha das experiências de campo e as descobertas de pesquisa que eram apresentadas nessas reuniões. No entanto, mais do que pelo brilhantismo de suas teorias e ideias, aprendíamos, com nossos mestres, 
que ciência se faz com afeto. Muitas, longas e profundas amizades foram gestadas e alimentadas no e a partir do ISER por essa geração de cientistas sociais que havia escolhido a religião não apenas como seu objeto de pesquisa, mas, sobretudo, como uma ótica através da qual olhar para a sociedade e para a cultura. E, da arte de juntar conhecimento e afeto, Pierre foi um destacado praticante. Em seu texto "A graça e a gratidão", ele fala de sua experiência no ISER.

Não podia adivinhar que, a partir daqui e pelo Brasil afora, os encontros regulares de antropólogos e de cientistas sociais, os convites, as pesquisas em comum, as participações em comissões daqueles órgãos que nos congregam e nos ajudam, me ofereceriam tantas riquezas de convivência, de articulações, de aprofundamento científico e de descobertas. De amizade. Teia de laços dos quais destaco, entre os mais antigos, estáveis e gratos, aqueles formados no Instituto de Estudos da Religião, do Rio de Janeiro (Sanchis 2003b:160).

Ainda que possa me situar na teia de laços de amizade, assinalada por Pierre acima, a minha relação com ele foi estabelecida, e assim se manteve por toda a vida, como uma relação entre o mestre e o aprendiz, orientada pelo vínculo transferencial do reconhecimento e da admiração. Uma amizade forjada em longas conversas e convivências a partir de nossas afinidades intelectuais, mas, também, por conta dos percursos semelhantes que fizemos - do pertencimento religioso ao estudo da religião - em tempos e por caminhos diversos. E, neste sentido, Pierre possuía sensibilidade profunda, adquirida no exercício da convivência com "o outro", no caso, os mais jovens, que, num processo de contratransferência, ao mesmo tempo que o mestre se diferencia do aprendiz, também é capaz de reconhecer-se nele e com ele aprender, invertendo o sentido da relação. As palavras dele, dirigidas aos estudantes, no evento de Belo Horizonte, deixam transparecer mais essa virtude.

Não podia adivinhar o quanto os estudantes me estimulariam por suas expectativas, me cercariam de delicadezas e deferências crescentes à medida em que os cabelos iam embranquecendo, me ajudariam a pensar, a conhecer um pouco mais o campo empírico ao qual, afinal, me dediquei - pois todos nós sabemos que este trabalho vai se elaborando em comum, o professor também aprendendo nas suas aulas, na confecção das monografias, dissertações e teses que "orienta" (a bela palavra), nas pesquisas onde iniciantes acompanham e ao mesmo tempo enriquecem seu caminhar (Sanchis 2003b:160).

Ainda, sobre amizade, é preciso lembrar a delicadeza de Pierre. As suas referências reiteradas às fronteiras porosas das culturas e dos grupos sociais parece en- 
contrar uma correspondência no nível pessoal das relações intersubjetivas que ele viveu ao longo de sua vida. Ou seja, assim como os coletivos humanos, os indivíduos também se constituem nos interstícios do encontro com o outro, onde se articulam as diferenças, mas também se consolidam as afinidades. Se as fronteiras dos grupos sociais são porosas, também o é a pele humana. Na convivência com os amigos, colegas, estudantes, ele sempre se mostrava aberto e receptivo. Sua pele não demarcava o limite de um sujeito encerrado em seu corpo, mas, ao contrário, a mediação ativa de acolhidas e trocas constantes. Esta porosidade e abertura foi sempre a fonte de sua delicadeza, que se expressa igualmente no estilo que ele imprime em seus textos acadêmicos e nas relações pessoais. Diz Pierre:

Em todo caso, a minha problemática identitária passou, doravante a ser dotada de um caráter ainda mais marcadamente múltiplo. Com a particularidade de que, cada vez mais, o problema aparecia-me como sua própria solução. Ou, pelo menos, como exigência do caminho em direção a ela: uma identidade plural não seria mais um obstáculo a contornar ou um peso a resolver, mas uma riqueza potencial a ser (dificilmente, às vezes) explorada na sua própria lógica, de articulação e não de exclusivismo (Sanchis 2003b:163-164).

Por fim, na categoria de amigos, podemos situar os seus mestres, a quem ele presta uma homenagem em sua fala "A graça e a gratidão", no evento em Belo Horizonte. Introduz suas afinidades com os mestres que o inspiraram, conectando-as à sua experiência pessoal. Em sua homenagem aos mestres, mais do que destacar suas teorias e contribuições, retirando-as da relação pessoal, ele as insere no processo dialógico da aprendizagem da antropologia. Assim, temas e questões que, desde sempre, lhe foram vitais, agora, no contexto acadêmico, são revisitados e reconsiderados sob a ótica das ciências sociais. Aqui, mais uma vez, o afeto e o conhecimento entrelaçamse. Suas escolhas temáticas resultam não apenas de uma curiosidade científica, mas, sobretudo, da sua inserção nos contextos de pesquisa e da relação com seus mestres. Este aprendizado, que não separa o conhecimento da vida, Pierre vai reproduzir nos diferentes contextos em que atuou: no ISER, nas associações e entidades científicas, nos congressos, nas bancas de defesa de teses e dissertações, assim como na universidade, junto de seus estudantes e colegas. Mas, também, em sentido reverso, no convívio com a família e os amigos. Como ele afirma: "Os temas que então me solicitavam, sob a influência, não casual, de três mestres hoje desaparecidos: Roger Bastide, suas Américas Negras e seu Brasil sincrético, Robert Jaulin, teórico do "etnocídio" e Henri Desroche, iniciador de uma produtiva corrente de Sociologia da Religião, também me confirmavam nessas descobertas" (Sanchis 2003b:164).

Enfim, podemos ver, novamente, como questões que são centrais para ele, que o acompanham desde a infância, retornam no contexto acadêmico. Ou seja, a 
atividade acadêmica não o leva a um distanciamento em relação ao seu objeto de pesquisa, como propõe a vulgata do método científico, mas, ao contrário, o conduz a um engajamento ainda mais visceral com o mundo da vida. Em sua relação com seus temas de pesquisa e no exercício do trabalho profissional, o vemos sempre implicado de corpo e alma. A vida pulsa, apaixonadamente, todo o tempo, igualmente, no seu trabalho de pesquisa, no ensino e nos seus textos. Não há em Pierre uma separação entre o campo, lugar distante, e o cotidiano, onde ele vive e aprende. Sua busca constante por conhecer o outro, nas suas múltiplas identidades, o conduz, sempre de novo, ao conhecimento de si e vice-versa.

\section{Religião como vida e como objeto}

A questão do pertencimento religioso, que precedeu ao seu engajamento com a antropologia, esteve sempre latente em sua vida. Não como o recalcado, certamente, mas como uma experiência forte e profunda, que ele busca, todo o tempo, articular com o trabalho da pesquisa científica. Lógicas distintas de aproximação com a religião, uma "pelo caminho da procura vivencial, de colorido místico, outra por uma abordagem que se pensa e se quer estritamente racional e objetiva" (Sanchis 2003b:167). Ainda que possam ser tomadas como etapas que se sucedem no tempo de sua existência, elas não subsumem uma na outra; pelo contrário, operam, em sua vida e em seu pensamento, como forças relativizadoras, que não permitem absolutizar qualquer um dos polos dessa tensão. Ter vivido a mística, como uma radical e profunda experiência de fé, torna possível perceber que, por mais brilhante e sedutora que se apresente a análise científica, há sempre algo, uma vez experimentado na própria carne, que escapa nas tentativas reiteradas da ciência em capturar o mistério. Aqui, é preciso dizer, contudo, que não estamos afirmando que os cientistas precisariam passar por uma experiência mística para aprender a relativizar. Certamente, outros cientistas podem encontrar, no repertório das experiências que os constituem, outras referências para narrar o processo que os conduziu à relativização. Mas, na vida de Pierre, a experiência mística foi, com certeza, fundamental para o exercício do seu ofício de antropólogo.

Sobre esta questão, que nos tocava a ambos, de modo muito íntimo, mantive longas e profícuas conversas com Pierre. Havia um nó górdio a desatar: como assumir uma posição que preservasse o cientista social tanto de cair num redutivismo analítico quanto numa compreensão iniciática do fenômeno estudado. Acreditávamos que nossa vivência pregressa relacionada à religião haveria de nos preservar em relação a esse risco ${ }^{5}$. Afinal, havíamos experimentado os limites de ambos os contextos. Por outro lado, os fios que se entrelaçavam nesse nó remetiam sempre de novo à imbricação profunda entre a nossa experiência vivida e a escolha da antropologia. Mais uma vez, a disjunção e a contradição surgem como uma encruzilhada fundadora (Sanchis 2003b:165), reiterando a mesma lógica das identidades múltiplas, que já estava pre- 
sente na sua infância. No encontro de Belo Horizonte, Pierre fala desta crise, que se instaura pela contradição entre a experiência mística e a elaboração científica, como uma frustração profunda ou um mal-estar, que encontrará, na antropologia, uma síntese dialética, ainda que provisória.

Essa alusão à religião me leva a outra frustração, menos relacional, mais pessoal e talvez mais funda. Quando um dia uma trajetória de reflexão e de vida se inflete radicalmente, trocando, no envolvimento com a dimensão religiosa, o caminho da procura vivencial, de colorido místico, pelo de uma abordagem que se pensa e se quer estritamente racional e objetiva, em busca de certezas mais definitivas e convincentes, pode acontecer que essa trajetória entre nas particularidades da Antropologia mais uma aporia que, desta vez, parece barrar-lhe o caminho da achega racional plenificante que se propunha (Sanchis 2003b:167).

Mas, se os contextos e as experiências são diversos na ordem do vivido, na da estrutura são vistos "como mais um caso entre os precedentes, aberto, também ele a uma superação dialética” (Sanchis 2003b:167). Aqui, Pierre igualmente aponta para a articulação como caminho possível de superação da absolutização de perspectivas únicas. "Articular", como ele dirá, "passou a ser meu mote" (Sanchis 2003b:165). Uma articulação que não dilui as tensões, é preciso dizer, nem na experiência existencial do sujeito nem no espaço social, mas que possibilita a convivência consigo e com o outro. Nesse sentido, ele estabelece uma correspondência entre a experiência mais decisiva de sua infância e o seu momento iniciático de entrada no campo das ciências. Como o menino catalão - dividido entre uma identidade regional, topologicamente enraizada no território, e outra nacional, produzida pela ação racionalizadora do Estado -, ele se encontra, mais uma vez, diante do desafio de inscrever corporalmente, nesta nova totalidade identitária, de antropólogo, aquilo que o constituiu, até aquele momento, como sujeito. Ou seja, não se trata de recalcar suas raízes, mas de se manter vigilante contra o unilateralismo excludente que tende a se impor tanto do lado da religião, que sempre corre o risco de dar origem a fundamentalismos religiosos e étnicos, quanto da ciência que, em nome do distanciamento epistemológico entre sujeito e objeto e da preservação do exercício racional de qualquer interferência e contaminação externa, acaba por produzir um conhecimento descolado da vida que pulsa nos indivíduos e nos coletivos.

\section{A sedução da antropologia}

A antropologia surge na vida de Pierre, como já referimos acima, como uma vocação, um chamado, uma escolha e uma maneira particular de habitar e conhecer o mundo. Sua relação com a antropologia é existencial e apaixonada. Vai muito além 
do domínio específico de uma metodologia ou técnica de pesquisa ou do reconhecimento de sua pertença afetiva e teórica a uma comunidade de pensamento ou, ainda, de uma disciplina inserida numa determinada área do conhecimento. Tornar-se antropólogo, se, de um lado, carrega um sentido iniciático, que inclui alguns rituais de passagem - ida a campo, defesas da dissertação e da tese, ingresso num departamento de ciências sociais -, de outro, é vivido por ele como uma vocação que esteve sempre presente, de forma latente, em parte inconsciente, desde sua infância. Uma escolha que se renova ao longo de toda sua vida, especialmente em contextos de crise, quando se impõe a necessidade de lidar com as contradições e tensões em sua vida pessoal ou profissional. "Essa série impressionante de situações na minha vida explica, em boa parte, a escolha que fiz da antropologia quando reorientei minhas atividades, minhas preocupações, minha vontade de entender e de marcar em modesta medida este mundo que era o meu" (Sanchis 2003b:163).

Sua descoberta apaixonada do Brasil, como ele relata, intensificou sua percepção de que, para lidar com as identidades múltiplas, que nos constituem como sujeitos e que atravessam tanto os grupos sociais quanto as culturas, era preciso compatibilizar construções teóricas contrárias. E ele vislumbra na antropologia a ciência que poderia dar conta deste imbróglio. Assim, ainda nos anos 1960, trabalhando num organismo da Igreja Católica, em Petrópolis, que "se dava por finalidade apresentar o Brasil para pessoas que vinham em missão humanitária, fundamentalmente missionários, mas também profissionais de outras áreas" (Sanchis 2003b:163), Pierre procura o recémfundado Mestrado em Antropologia do Museu Nacional, na expectativa de que os antropólogos que ali ensinavam pudessem ajudá-lo.

Ora, precisamente a antropologia continuou me seduzir porque sempre pareceu-me encontrar nela, longe do fácil ecletismo de que às vezes é suspeita, a possibilidade de uma articulação das abordagens diferentes, de uma convivência das construções teóricas contrárias, de não-absolutização de perspectivas únicas. A seu propósito já falei em encruzilhada fundadora. Ela me parece, com efeito, nascer amoldada a um espaço epistemológico de tensões. Daí lhe advém dinamismo, polivalência, virtual potência explicativa (Sanchis 2003b:165).

Sua opção pela antropologia, no entanto, possui outra motivação, para além do solo existencial e prático em que transcorre a vida humana no seu cotidiano. Ela se inscrevle também na ordem epistemológica, do conhecimento e da teoria. A sua escolha funda-se, portanto, no reconhecimento da especificidade metodológica e heurística que distinguiria a antropologia no horizonte das ciências sociais. Pierre percebe, na antropologia, um instrumento singular, capaz de produzir inteligibilidade à diversidade que constitui o real. Ao mesmo tempo, chama a atenção para o lugar do antropólogo como eterno discordante e de objetor sistemático, na medida em que ele 
levanta a contradição, mesmo diante de afirmações, abordagens e descobertas com as quais concorda. Afinal, sempre é preciso resgatar o ponto de vista oposto, mesmo porque nenhuma descoberta, por mais pertinente e verdadeira que possa ser, anula a diferença ou esgota os sentidos da realidade.

Sua intencionalidade fundamental [da antropologia] já pode distingui-la entre as ciências, quem sabe até entre as ciências sociais: ela está dilacerada entre as exigências das duas linhas que mobilizam os pensadores desde os albores da modernidade, o racionalismo universalista, grande lição do iluminismo, e certo romantismo particularista e existencial. As metamorfoses do individualismo trafegam nessa encruzilhada, enquanto a apreensão de totalidades pode mudar de nível e de amplitude, mas nunca deixa de estar presente (Sanchis 2003b:165).

Na perspectiva de Pierre, entretanto, não se trata de optar por um ou outro desses lados, o universalismo iluminista ou o particularismo romântico, mas de tomá-los como complementares, sem, contudo, enveredar para um relativismo multiculturalista. Ou seja, a tensão permanente, instaurada por essa encruzilhada, é o que permite perceber a complexidade do fenômeno que se revela sempre, e ao mesmo tempo, como particular/local e universal/global. Não cabe aqui, portanto, eleger uma ou outra dessas perspectivas, mas articulá-las, de modo a construir evidências de que nenhuma delas possa se apresentar como única, na medida em que se deixam questionar pelo reconhecimento da posição que parece contradizê-las. Para Pierre, desta tensão, decorreriam as aporias fundadoras da antropologia, que ele nomeia como: identidade ou alteridade, diversidade múltipla ou universalidade, razão analítica ou razão simbólica. Assim como os problemas que o habitam desde sua infância: exclusiva razão ou/e potência noética da emoção, biologia e/ou construção social, realidade e/ou representação, identidade recebida e/ou identidade construída, universalismo e/ou cultura, cultura e/ou ação do agente social, estrutura e/ou história (Sanchis 2003b:165). O caminho que ele toma, porém, não é o de diluir, na análise, a ambiguidade epistêmica dessas aporias ou de aplainar as contradições inerentes aos problemas que se interpõem em suas reiteradas tentativas de sínteses pessoais e teóricas. Ao contrário, como ele afirma:

Quanto a mim, sempre aconteceu-me, ao encontrar uma ou outra dessas pontas, quando não uma e outra, na mesma monografia ou síntese teórica, ou ainda em posições adversas de pesquisadores diferentes (e até, por que não, de "clássicos"), de recebê-las, mesmo se à revelia dos seus autores [...]. Mais ainda: chego a aceitar e a admirar a proclamada inteireza de determinada afirmação parcial quando leva a instigantes descobertas, sabendo que é no campo global da produção antropológica que ela encontrará o seu contraponto (Sanchis 2003b:165-166). 
Seu posicionamento, no debate das correntes teóricas que atravessam o campo da antropologia, alinha-se com a tradição estruturalista francesa, na qual ele inscreve seu conceito de sincretismo, compreendido como uma estrutura possivelmente universal na história das religiões, mas que também se encontraria em todas as demais dimensões da vida social e psíquica das sociedades e dos indivíduos (Sanchis 2001:9). Neste horizonte, a tarefa que ele se impõe, que o ocupará intensamente ao longo de toda sua vida como intelectual, será a de transpor o sincretismo da ordem do particular e pensá-lo como um universal. O que, ele mesmo o reconhece, teria uma correspondência com o que Lévi-Strauss fez com o totemismo e a dádiva em relação a Durkheim e a Mauss, respectivamente. É a partir desse horizonte teórico que Pierre define sincretismo como "um modo pelo qual as sociedades humanas (sociedades; sub-sociedades; grupos sociais; culturas; subculturas) são levadas a entrar num processo de redefinição de sua própria identidade, quando confrontadas com o sistema simbólico de outra sociedade, seja ela de nível classificatório homólogo ao seu ou não" (Sanchis 1994a:7).

Será, portanto, no encontro que o sincretismo opera: como um recurso que os coletivos humanos utilizam para ressemantizar em seu próprio universo as relações apreendidas no mundo do outro. Mas, se o recurso é universal, o modo como cada um desses coletivos o opera é particular. Para dar conta desta articulação entre o particular e o universal, Pierre vai incorporar, em sua análise, o conceito de habitus que ocupa um lugar central para o seu pensamento ${ }^{6}$. Esse conceito é o que lhe permite afastar-se do formalismo linguístico ou matemático, que reduz a estrutura a um princípio a-histórico e imóvel, e introduzir a diacronia no seu interior. O sincretismo como habitus é o que o possibilita escrever, quase à exaustação, sobre identidades porosas que se estabelecem, mediante processos de longa e de curta durações. $\mathrm{Ou}$ seja, dirá Pierre, toda identidade é atravessada por relações de poder, permeadas por negociações, articulações, conflitos, dominações, resistências e resiliências. Será, a partir deste ponto de vista, que ele fará a crítica às correntes pós-estruturalistas e anticulturalistas. Como podemos ver no excerto transcrito abaixo, a adesão ao novo, na teoria antropológica, deve inscrever-se na linha da tradição sedimentada na área.

É evidente que as minhas incitações iniciais em direção à antropologia, tal como as descrevi, poderiam facilmente apontar para problemáticas antigas e que a muitos parecem ultrapassadas. Tudo o que lembra o culturalismo cheira hoje à estática e à camisa de força... Enquanto alguns de nossos colegas historiadores, inspirados, dizem eles, pela antropologia, reatam relações com uma longa duração que impõe a ideia de estrutura, nós nos tornamos mais sensíveis ao acontecimento, à emergência do novo, ao não marcado, ao fluido. Fluxos, mais do que substância; redes, mais do que instituições. O espetáculo da realidade do nosso tempo nos inspira a construção de instrumentos de análise cuja 
implicação podemos ser tentados a estender à totalidade do campo social, diacrônica e sincronicamente (Sanchis 2003b:165).

Enfim, diante de uma tendência atual da antropologia de revisão dos conceitos de cultura e instituição, marcados pela tradição funcionalista, que dominou a área até os anos de 1980, Pierre alinha-se com aqueles que, sem descartar esses conceitos, vão tensioná-los por meio da articulação constante entre sincronia e diacronia. Cultura e instituição, na sua análise, não se diluem em fluxos, redes e malhas, mas estão sempre presentes como "estruturas na conjuntura" . Sua busca incessante pelas origens está alicerçada não na ideia de um determinismo histórico, mas na crença de que "o início de um fato social contribui para montar, no sistema sociocultural e psicossocial, que caracteriza os seus atores, um habitus que tenderá, por sua vez, a marcar a 'longa duração' de sua presença" (Sanchis 2003a:29). Contudo, como ele bem mostra em relação à "cultura católica brasileira", as suas raízes são múltiplas, assim como as identidades sincrônicas e diacrônicas que elas engendram (Sanchis 1994b:46). Este fato, no entanto, não dirime a necessidade de buscar um núcleo ou polo articulador, sempre histórico e sujeito à mudança, que caracterizaria essa cultura e a diferenciaria de outras. E será o exercício rigoroso e sistemático de perscrutar e explicitar continuidades e rupturas no movimento e na cultura que definirá fundamentalmente o seu ofício e a sua missão como antropólogo.

\section{As lições da antropologia para a política}

Esta perspectiva epistemológica, por sua vez, tem seu desdobramento no seu posicionamento político diante dos unilateralismos e fundamentalismos étnicos e religiosos presentes no mundo contemporâneo. Como ele mesmo afirma: "todos os conflitos armados que hoje ensanguentam o nosso mundo desdobram-se em torno de identidades étnicas, de relação com uma terra e de definição coletiva através da religião" (Sanchis 2003b:167). O caminho que aponta para o enfrentamento desse desafio seria o de um gerenciamento convivial das identidades coletivas, para o qual a antropologia teria uma contribuição ímpar a oferecer, na medida em que ela nos ajuda a perceber que as identidades sociais são sempre plurais. Às identidades plurais, Pierre contrapõe as identidades mortiferas, que seriam aquelas que se pretendem limitadas a uma pertença única ${ }^{8}$. Assim, dirá, com o intuito de mostrar a face pública da antropologia:

A antropologia, que, privilegiando o estudo do quotidiano e das relações miúdas, podia aparecer a alguns como afastada dos problemas candentes do mundo contemporâneo, constitui, na verdade, para a modernidade, graças a seu enfoque comparativo, um rico instrumento de reflexão autocrítica. Nesse sentido, seria ilusão pensar que sua temática atual a leva para longe das preocupações, sociais e políticas, que marcaram mais 
visivelmente, em outras épocas, a nossa história de cientistas sociais no Brasil (Sanchis 2003b:168-169).

Todavia, apontará Pierre, as lições da antropologia para o exercício da política são sempre contextuais. Neste sentido, adverte-nos de que, em situações de "opressão das culturas, mesmo quando feita em nome de uma modernidade libertadora, [...] é perfeitamente sadia a operação de reencontrar, recuperar ou, quem sabe, reinventar raízes" (Sanchis 2003b:168). Mesmo porque, como afirma na sequência, "o cultivo de identidades herdadas também pode ser preâmbulo para uma troca não vazia de um intercâmbio enriquecedor"; afinal, dirá, "não se dialoga senão a partir do que se é ou do que se pensa que se é" (Sanchis 2003b:168). Aqui, no entanto, faz uma importante ressalva, lembrando-nos que essas identidades devem ser "gerenciadas prospectivamente no sentido da autonomia do indivíduo e articuladas, subjetivamente, com os valores universais da modernidade" (Sanchis 2003b:168). Porém, ele irá concluir esse tópico, afirmando que não há uma teleologia nesse movimento da política das identidades. Não sabemos para onde nos conduzirá um ou outro dos caminhos seguidos. Em ambos, há riscos. Se o pluralismo identitário pode levar à diluição do vínculo narcísico primário, fundante do laço social, num universalismo vazio, o cultivo de identidades herdadas pode levar a um fechamento do grupo, fazendo com que o eco do seu passado predetermine totalmente o seu futuro. Para ambos, afirma Pierre, cabe a advertência de Lévi-Strauss, em relação às culturas, de "afirmar-se na abertura e de tornar-se porosas aos desafios de uma ressemantização exigida pelo encontro dos outros" (Sanchis 2003b:168).

Um outro nível da política, para o qual Pierre acena em "A graça e a gratidão", é o da política institucional. A criação de um Programa de Pós-Graduação em Antropologia é um projeto ao qual ele se dedicou, juntamente com seus colegas do Departamento de Antropologia da UFMG, durante todo o período em que esteve atuando na universidade. E, oportunamente, ele associa a homenagem, que lhe estava sendo prestada pela UFMG, à criação da pós-graduação em antropologia. Ademais, vai demarcar esse evento como o início de uma nova etapa para a antropologia na instituição, o que, na verdade, iria acontecer sete anos depois, quando o Mestrado em Antropologia e Arqueologia da UFMG selecionou sua primeira turma. Suas palavras, neste sentido, são de expectativa e esperança.

Por isso, não deixa de ser triste o caráter institucionalmente embrionário [da antropologia] na Universidade Federal de Minas Gerais, uma das mais significativas do país. Fico feliz em pensar que esta situação está para mudar. $\mathrm{O}$ encontro destes dias inaugura, esperamo-lo, uma nova etapa institucional da antropologia em Minas Gerais. Com o apoio das autoridades da Universidade e da Faculdade, a colaboração fraterna do Mestrado em Sociologia e o Doutorado em Sociologia e Política, em ar- 
ticulação com a área de antropologia e também a colaboração preciosa dos Programas de há muito assentados em outras universidades, aproxima-se a abertura, por muitos esperada, de uma Pós-Graduação em Antropologia. Dizer isso, hoje, para mim é uma grande alegria. Pois me dá a certeza de que, se uma página, bem modesta, foi encerrada neste clima de carinho com que a quiseram marcar, outra se abre, promissora em nível maior para o Departamento, seus professores e estudantes, para o público de Minas Gerais, para a Faculdade, a Universidade. Uma das múltiplas iniciativas que devem contribuir para a cultura no Brasil (Sanchis 2003b:169).

Concluindo este tópico, gostaria de chamar a atenção do leitor para um texto de Pierre, publicado na seção Espaço Aberto da revista Horizontes Antropológicos, de 1999, intitulado "Impressões da Rússia", a respeito da viagem que ele fez àquele país, para participar de um evento científico (Sanchis 1999a). As suas impressões, tecidas a partir da observação in loco e de conversas com colegas, com estudantes e seus familiares, com jornalistas e atendentes do hotel, revelam um olhar etnográfico que procura explicitar a carga simbólica e histórica que adensam os fatos econômicos e políticos da vida social pós-socialista. Ou seja, a conjuntura econômica e política, mesmo num relato pessoal de viagem, será apreendida diacronicamente, à luz de dois fatos fundamentais da história da Rússia: o czarismo e o socialismo. Assim, se é verdade, dirá Pierre, que o regime soviético conseguiu incutir, na sociedade, um habitus de responsabilidade e solidariedade, também é preciso reconhecer que isto não anulou o habitus de obediência e disciplina, do período pré-revolucionário. Eles aí estão, articulados e indissoluvelmente misturados, delineando uma cultura singular, pós-socialista, mas também pós-czarista. Ao antropólogo, portanto, cabe assinalar as marcas de ambos, presentes na conjuntura como forças estruturantes da vida social.

\section{Conclusão}

Ao encaminhar este artigo para um possível desfecho, permitam-me fazer referência ao último encontro que tive com Pierre, em outubro de 2016, quando, juntamente com Marcelo Camurça, fizemos uma visita a ele, em sua casa, em Belo Horizonte. Em determinado momento, a conversa enveredou para o projeto, encampado por alguns colegas, de reunir a sua produção, que se encontra dispersa em muitos artigos e capítulos de livros, numa coletânea editada. Embora insistíssemos na importância desse projeto, Pierre fez questão de manifestar sua preocupação e resistência em relação a ele. Argumentava, então, que seus textos traziam algumas repetições que tornariam vulnerável a proposta de reuni-los num livro. Naquele momento, como hoje, penso que as repetições, às quais ele se referia, mostram, na verdade, a força de sua reflexão. Mais, elas estão em total coerência com seu estilo de produzir 
conhecimento e sua prática antropológica. Suas afirmações e descobertas permanecem sempre abertas a reformulações e reinterpretações quer pelos arranjos criativos e inusitados que a relação permanente entre estrutura e evento pode ensejar, quer pela sua percepção da necessidade de incorporar, ainda que parcialmente, o ponto de vista do outro às nossas conclusões, sempre parciais e provisórias. É a partir desta ótica que gostaria, à guisa de conclusão, de trazer, aqui, alguns temas recorrentes da reflexão de Pierre que o tornaram um autor incontornável no campo das ciências sociais para muito além das fronteiras nacionais ou dos estudos da religião. Farei isso, primeiramente, citando um último excerto do artigo "A graça e a gratidão", que nos guiou até o momento. Nele, Pierre elenca aqueles temas que, de forma lancinante, vão acompanhá-lo ao longo de toda sua trajetória.

Atesta-o uma primeira dissertação sobre a significação sociológica e a repercussão nos meios de comunicação da liturgia católica com um revestimento cultural (musical) em parte negro, evocador do Candomblé, num tempo (1965) em que a sensibilidade da opinião nacional não lhe seria muito acolhedora. Brasil e Religião, Catolicismo e Negritude, cultura e identidade, todos temas que, lancinantes, vão me acompanhar, até a pesquisa recente sobre os Agentes de Pastoral Negros, militantes da Negritude Católica. Mas temas que também, cada um a seu modo, insistem sobre a problemática fundamental do que, para mim, constituirse-ia cada vez mais como a encruzilhada fundadora da Antropologia: unidade e diversidade, universalismo e diferenças (Sanchis 2003b:164).

Brasil e religião, com certeza, atravessam seu pensamento, como dois polos indissociáveis, ainda que cada um deles possa articular-se com os das outras dualidades, referidas acima. Há uma aposta, exaustivamente reiterada em sua análise, de que a religião seria a porta de entrada por excelência para se interpretar o Brasil. E ele vai fazer isso por meio de uma busca vertical das raízes estruturais do que nos constituiria como nação. Nessa busca, depara-se, primeiramente, com o catolicismo popular, das romarias e festas religiosas, forjado, em sua origem, em terras lusitanas, no veio de tradições pré-cristãs, de povos locais, romanos, bárbaros, mas também de mouros e judeus diaspóricos9. Esse catolicismo popular, no entanto, é visto por ele como indissociável do catolicismo institucional, emblematizado pela Igreja Católica, que o representa e corporifica diante das elites seculares e do Estado, que a ela se opõem como forças modernas e autônomas.

A segunda vertente, na formação do Brasil, seria representada pelas religiões de matriz africana. Também elas advenientes, como escreve Pierre, uma vez que, "radicadas em outro mundo e arrancadas de sua matriz geográfica e sociopolítica, souberam reelaborar, no Brasil, seu universo simbólico, suas organizações comunitárias e uma proposta religiosa universal, independente de nação, etnia ou cor" 
(Sanchis 2001:15). Portanto, já não mais africanas, mas afro-brasileiras, passando a compor, junto com a vertente do catolicismo ibérico, igualmente transladado do seu solo originário, a religião dos brasileiros ${ }^{10}$. Um catolicismo brasileiro, afirma Pierre, fundamentalmente sincrético e plural na sua origem. Ainda que, dirá ele, não se possa ignorar o contexto indígena, do seu enraizamento no Novo Mundo: uma terceira vertente que o catolicismo vai incorporar, de forma diferenciada - em algumas regiões em maior grau e noutras em menor. Entre essas vertentes, no entanto, há uma relação hierárquica, no sentido estabelecido por Louis Dumont, em que o catolicismo acaba por englobar as outras duas, sem, contudo, as diluir numa síntese homogênea que apagaria as diferenças que as tensionam. Esta experiência histórica, situada na origem da nação, teria, segundo Pierre, forjado uma estrutura ou uma lógica de longa duração, fundante daquilo que ele vai denominar - ainda que alerte o leitor para o caráter estranho da expressão - de cultura católico-brasileira (Sanchis 1994b:34).

Ao referir-se à cultura católico-brasileira, Pierre não está afirmando que ela se definiria por valores, dogmas ou princípios católicos, mesmo que esses conteúdos lhe sejam também constitutivos, mas, ao contrário, quer chamar a atenção para um jeito católico das coisas acontecerem e se instituírem no Brasil. Ou seja, o católico, aqui, remete fundamentalmente a um habitus, ou um tipo ideal, dirá noutros momentos, que, ainda que possa ter uma correspondência com um evento histórico, opera como "uma força motora, princípio de orientação da realidade, sempre em ação e sempre orientado na mesma direção" (Sanchis 2006:94). A partir desta ótica, as mudanças que ocorrem na cultura brasileira, tanto no sentido de uma incorporação do novo quanto de uma reformulação da tradição, aconteceriam orientadas por esse vetor. Isso, em hipótese alguma, indicaria um determinismo histórico, uma vez que, na sua concepção, esta força estrutural está na ordem do devir, como uma potência criativa, capaz de reorganizar os elementos que lhe são oferecidos de muitas e variadas maneiras.

Enfim, será na religião, como fato fundante da vida social, que Pierre encontra o ponto de ancoragem para traçar uma sociogênese do Brasil. Não a religião como um sistema unificado de dogmas, rituais, princípios morais articulados por uma instituição, mas a religião como expressão de um habitus, marcado, na origem, por uma encruzilhada fundadora de tradições desterritorializadas geograficamente, no caso dos portugueses e dos africanos, e culturalmente, no caso dos indígenas. O catolicismo institui-se como a religião dos brasileiros, na medida em que mantém, em seu núcleo, a força estruturante da diversidade e da pluralidade da origem. Neste sentido, seguindo o raciocínio de Pierre, se todas as religiões são sincréticas, algumas o são mais do que outras. E a dos brasileiros seria radicalmente sincrética, tendo em vista que o sincretismo está na sua raiz, como seu mito fundador. Portanto, não se trata de um sincretismo que opera apenas na ordem do evento, que resulta do encontro entre tradições ou culturas, potencializado pelos movimentos de globalização, migração e transnacionalização, que aproximam os diferentes, ensejando tanto conflitos, guerras e fundamentalismos quanto alianças, tolerâncias e apropriações mútuas. 
A segunda dualidade, referida acima por Pierre, é a que articula os polos $\mathrm{Ca}$ tolicismo e Negritude. Uma questão que, como ele afirma, se constitui no "eterno problema do pensamento social brasileiro, o problema da mestiçagem cultural, constantemente recalcado, mas teimoso no seu reaparecimento cíclico, que tem sua vertente religiosa na questão do sincretismo" (Sanchis 1999b:55). Um tema que, como vimos anteriormente, está no início de sua reflexão antropológica, como objeto de sua dissertação de mestrado, e que, como constata Cecília Mariz, "a partir de 1994 a maior parte dos textos de Pierre Sanchis propõe reabilitar o conceito de sincretismo, apontando para seu enorme potencial analítico" (Mariz 2005:191). Um instrumento valioso para a análise de processos sociais, mesmo daqueles que, legitimamente, prescindem dele ou a ele se opõem na elaboração de sua consciência reflexiva. Dois mundos diferentes - o católico e o africano - na sua raiz ritual, na sua intencionalidade simbólica, na ordenação das relações humanas que eles inspiram. Mas totalmente imbricados entre si, de modo que se torna impossível pensar as religiões africanas sem a impregnação católica que as constitui, assim como seria impossível imaginar nosso catolicismo despido de ressonâncias africanas. Tal implicação mútua o levará a afirmar que o candomblé e a umbanda seriam "duas modalidades de fidelidade criativa - e brasileira, quer dizer, católica” (Sanchis 1994b:34).

Catolicismo e negritude surgem, assim, em sua análise, como matrizes primordiais na constituição do campo religioso popular brasileiro. A elas, outras se juntarão, no decorrer da história do Brasil, compondo a diversidade de tradições que circulam e se articulam no espaço público da nação: indígenas, espíritas, protestantes, pentecostais, esotéricas, orientais. No entanto, dirá Pierre, "o que torna mais agudo o problema, aliás, é que, até o momento, não parece enfraquecer-se, na maioria dos casos, o reconhecimento da identidade matriz, a católica" (Sanchis 1999b:65). Esta relação estrutural, entre catolicismo e negritude, entretanto, ao mesmo tempo que permanece como um habitus que orienta a incorporação do novo, ensejando arranjos inesperados entre as múltiplas tradições que povoam o campo religioso brasileiro, também estaria perdendo sua força diante do decréscimo numérico e de hegemonia política dos católicos e do desafio que lhe é imposto por correntes religiosas antissincréticas. Ou seja, suas análises tanto do processo histórico de longa duração quanto do contexto atual do campo religioso contemporâneo levam-no a afirmar que a história do Brasil não é somente a da "saga do sincretismo, mas também, ao contrário, a história de uma relação dialética onde vetores sincréticos e antissincréticos se conformam num processo criativo" (Sanchis 2001:27). Cada religião e cultura estariam, segundo Pierre, atravessadas por várias linhas de continuidades que ligariam polos sincréticos a polos antissincréticos.

É nesta continuidade que Pierre introduz os conceitos de pré-moderno, moderno e pós-moderno, como ideais-tipos, que se articulam no campo social e das consciências individuais como diacronias que se sobrepõem na sincronia. "Estas três modernidades", dirá Pierre, "logicamente sucessivas, nele se articulam contempora- 
neamente e trançam-se entre si" (Sanchis 1997:112). O pré-moderno, vale dizer, o tradicional, representaria, idealmente, a dimensão sincrética da estrutura católica. Ela mesma, no entanto, tensionada, ao longo da história, pelos polos antissincréticos, incorporados pelos movimentos de modernização, que a atravessam desde a contrarreforma e a romanização até a Teologia da Libertação. Na atualidade, porém, o polo antissincrético estaria representado, sobretudo, pelos pentecostais que teriam ensejado um movimento moderno que, pela primeira vez na história do Brasil, em nível popular pelo menos, estaria alcançando a massa, produzindo uma ruptura em relação ao status quo da cultura católico-brasileira. Moderno, afirmará Pierre, "porque fundado sobre a opção pessoal e consciente de fé de cada um a Jesus, e não pela mediação da instituição, segundo a fórmula católica ('Creio na Igreja') que cada fiel é salvo, muda seu destino e, com ele, muda o mundo" (Sanchis 1997:107-108).

Uma modernidade que tem sua ponta de lance no pentecostalismo, mas que ocorre, igualmente, no interior do catolicismo e das religiões de matriz africana. No catolicismo, na direção dessa modernidade, multiplicam-se os movimentos que, em reação especular ao pentecostalismo, se empenham pela afirmação de uma identidade católica, também ela pessoal e consciente, forjada na disciplina, na ética e na adesão a uma comunidade congregacional. Já no campo das religiões de matriz africana, a modernidade poderia ser encontrada nas tentativas de purificação e restauração do candomblé que, libertado de qualquer contaminação sincrética com o catolicismo, deixaria de ser uma religião étnica e se transformaria numa religião universal. Estas novas identidades, forjadas dentro de uma lógica moderna, no entanto, não se instituem fora da tensão do campo religioso. Ao contrário, elas mesmas vão se articular com o pré-moderno, como no exemplo, analisado por Pierre, do dinheiro, no interior da "teologia da prosperidade", que estaria, ao mesmo tempo, inserido na lógica racional moderna do capital e na lógica sagrada da dádiva pré-moderna, em que, como sacramento, ele simboliza e realiza a entrega de si a Deus por meio da Igreja. Enfim, a análise de Pierre, reiterada por inúmeros exemplos de articulações criativas entre o moderno e o pré-moderno, vai, em última instância, revelar um campo religioso brasileiro atual no qual as religiões modernas, ao mesmo tempo que negam os mundos sagrados afro-brasileiro e católico, também possibilitam recapitulá-los e reinventá-los.

Neste campo religioso, emerge, finalmente, o pós-moderno, como mais uma lógica em ação, diversa das anteriores, uma vez que, como afirma Pierre, ela tende a produzir "uma construção eclética mais do que um sincretismo" (Sanchis 1997:104). Aponta, portanto, para uma outra direção: não a do sincretismo, que articula diferenças e universalidade, gerenciando em comum identidades diversas, mas para a multiplicação de colagens que resultam de recortes simbólicos, produzidos ao sabor de uma criatividade idiossincrática e radicalmente individual. Mais do que um modelo religioso, dirá Pierre, o pós-moderno produz um clima que envolve todas as religiões e instituições, "marcando-as com um traço de recentramento da função 
simbólica sobre a operação totalizante (holística) - embora não submetida a um eixo unificador - a partir das aspirações, das necessidades e dos fantasmas de um self indissoluvelmente espiritual e corporal" (Sanchis 1997:111). Surge, assim, na lente de observador do campo religioso atual, um ambiente de diversificado pluralismo interno e multiplicação de identidades, reatualizadas e reformuladas pelos efeitos desse clima pós-moderno. Um processo em que não só se modifica o mapa das religiões no Brasil, mas a própria religião perde seus sentidos tradicionais e suas antigas funções, ao mesmo tempo que adquire novos.

Cultura e identidade é a terceira dualidade referida por Pierre. Ainda que já tenhamos tratado dela nos itens anteriores que entrelaçam a tessitura desta conclusão, cabe aqui algumas considerações para fechar este texto. A primeira é a de que a cultura se define, fundamentalmente, a partir da estrutura. Seu movimento, semelhante àquele empreendido por Marshall Sahlins, será menos o de pensar as culturas como totalidades autônomas, demarcadas por fronteiras rígidas, e mais a de perscrutar, na história e na conjuntura dos coletivos humanos, a persistência de uma estrutura de longa duração que as atravessa, conferindo-lhes alguns elementos comuns de identificação e reconhecimento mútuos que sustam algum sentido de pertencimento. Será, portanto, não no interior das culturas, mas nas suas fronteiras que estes dois termos, cultura e identidade, se articulam.

Ao situar a especificidade da cultura na ordem da estrutura, Pierre afasta-se, primeiramente, de uma concepção essencialista que a define a partir de um sentido unificado, que operaria como denominador comum para o conjunto de elementos básicos, compartilhados igualmente por todos que pertenceriam àquela cultura. Afasta-se, também, da ideia de cultura como uma espécie de sistema de significados e de valores, que pairaria acima dos indivíduos. Ou, ainda, da cultura pensada como um acervo de recursos, guardado em algum lugar mítico, ao qual os membros daquela cultura, e somente eles, teriam acesso. Qualquer cultura, apontará Pierre, será sempre plural, múltipla e diversa ou não será cultura. Será ideologia, crença ou utopia.

Os dois termos da dualidade, cultura e identidade, articulam-se no pensamento de Pierre a partir da presença do outro. Sem o confronto e o desafio do outro, a cultura não será percebida como unidade nem produzirá os pontos de convergência, indispensáveis para produzir identidades. Mas, para Pierre, este outro, ainda que possa ser adveniente, nunca está fora da cultura, e sim a atravessa e se refrata em muitos outros, redefinindo continuamente suas margens. Portanto, se há fronteiras, elas são sempre móveis e impermanentes. E se há identidades, elas estão sempre em movimento, reinventando-se e ressematizando-se, ainda que, disto Pierre não abre mão, seja possível perceber, na mudança, algo que permanece, mesmo que no e depois do encontro com o outro ele já não seja mais o mesmo. Porém, o outro também não o será. O encontro, portanto, afeta ambos.

Enfim, embora a análise de Pierre se processe sob o signo da mudança, esta opera a partir de um fundo básico, um princípio, um habitus, cuja ausência signifi- 
caria uma dispersão total e uma confusão desagregadora. Esse fundo básico, por sua vez, possui como referência um mito fundador que, apesar de poder ser localizado na história, atua como uma força inconsciente, estrutural, a-histórica e permanente, sem a qual a vida social se inviabilizaria totalmente. Será, portanto, em referência a este mito de origem que as identidades se produzem, continuamente, reafirmando-o ou negando-o. No caso brasileiro, como vimos, Pierre o reconhece como um habitus católico, instituinte de uma cultura mestiça que perceberia, como sua marca fundante, não a unidade ou a pureza na origem, mas sim a "porosidade de identidades e a ambivalência dos valores, uma tendência, sempre frustrada mas permanentemente retomada, em direção à conjugação do múltiplo numa unidade nunca atingida" (Sanchis 2001:46). É o percurso desta cultura católico-brasileira na história, sua permanência, seus desafios, suas transformações e reformulações que constitui a questão existencial e teórica que mobiliza Pierre e o leva a um engajamento de corpo e alma na antropologia, acreditando que ela teria, mais do que qualquer outra ciência, a possibilidade de jogar alguma luz sobre essa realidade.

O estudo da cultura brasileira teria, ainda, para Pierre, um sentido político que transcenderia o nível nacional, revestindo-o de uma importância global. Partindo da premissa de que o problema fundamental, enfrentado pela humanidade hoje, seja o de articular universalismo e diferenças e o de gerenciar em comum identidades étnicas e religiosas múltiplas, ele se pergunta se o estudo do modelo histórico brasileiro, apesar de suas ambivalências, não poderia trazer importantes contribuições práticas no nível da ação política. E vai mais longe, afirmando que uma melhor compreensão da problemática que se desenha no campo da religião poderia contribuir significativamente para o gerenciamento das identidades coletivas no âmbito político, de modo que o sincretismo pode ser denominado como "um dos nomes contemporâneos do problema da Paz" (Sanchis 1999b:65).

\section{Referências Bibliográficas}

CAMURÇA, Marcelo. (2001), "Da boa e da má vontade para com a religião dos cientistas sociais da religião brasileiros". Religião E̊ Sociedade, vol. 21, no 1: 67-89.

FRIGERIO, Alejandro. (2005), "Identidades porosas, estructuras sincréticas y narrativas dominantes: miradas cruzadas entre Pierre Sanchis y la Argentina”. Ciencias Sociales y Religión/Ciências Sociais e Religião, nํㅜ 7: 223-237.

MARIZ, Cecília. (2005), "De vuelta al baile del sincretismo: un dialogo con Pierre Sanchis". Ciencias Sociales y Religión/Ciências Sociais e Religião, no 7: 189-201.

ORO, Ari Pedro. (2018), "A herança durkheimiana na revista Archives de Sciences Sociales des Religions". Ciencias Sociales y Religión/Ciências Sociais e Religião, no 28: 99-113.

PEREZ, Léa e SANTOS, André. (2005), "Pierre Sanchis e o exercício escrupuloso do ofício: nos rastros de suas nascentes, as romarias portuguesas”. Ciencias Sociales y Religión/Ciências Sociais e Religião, n⿳亠 7: 211-221.

PIERUCCI, Antônio Flávio. (1997), "Interesses religiosos dos sociólogos da religião". In: A. Oro e C. 
Steil (orgs.). Globalização e religião. Petrópolis: Vozes.

. (1999), "Sociologia da religião - área impuramente acadêmica". In: S. Miceli (org.). O que

ler na ciência social brasileira (1970-1995). Vol. 2 Sociologia. São Paulo/Brasília: Editora Sumaré/

ANPOCS/CAPES.

SAHLINS, Marshall. (1990), Ilhas de história. Rio de Janeiro: Jorge Zahar.

SANCHIS, Pierre. (1983), Arraial: Festa de um povo. As romarias portuguesas. Lisboa: Dom Quixote. . (1986), "Uma identidade católica?". Comunicações do ISER, vol. 22: 5-16.

(org.). (1992a), Catolicismo: modernidade e tradição. São Paulo: Loyola.

(org.). (1992b), Catolicismo: cotidiano e movimentos. São Paulo: Loyola.

(org.). (1992c), Catolicismo: unidade religiosa e pluralismo cultural. São Paulo: Loyola.

. (1994a), "Pra não dizer que não falei de sincretismo". Comunicações do ISER, no 45: 4-11.

. (1994b), "O repto pentecostal à cultura católico-brasileira". In: A. Antoniazzi (org.). Nem anjos

nem demônios: interpretações sociológicas do pentecostalismo. Petrópolis: Vozes.

. (1997), "O campo religioso contemporâneo no Brasil". In: A. Oro e C. Steil (orgs.). Globaliza-

ção e religião. Petrópolis: Vozes.

. (1999a), "Impressões da Rússia". Horizontes Antropológicos, no 12: 297-325.

. (1999b), "Inculturação? Da cultura à identidade, um itinerário político do campo religioso: o

caso dos Agentes de Pastoral Negros". Religião Eु Sociedade, vol. 20, nº 2: 55-72.

. (2001), Fiéis e cidadãos. Percursos do sincretismo no Brasil. Rio de Janeiro: Editora da UERJ.

. (2003a), "A religião dos brasileiros". Teoria e Sociedade, no especial: 16-49.

. (2003b), "A graça e a gratidão". Teoria e Sociedade, no especial: 158-169.

. (2006), "Peregrinação e romaria: um lugar para o turismo religioso". Ciencias Sociales y Religión/

Ciências Sociais e Religião, no 8: 85-97.

SEMÁN, Pablo. (2005), "Pierre Sanchis en la coyuntura de las ciencias sociales de la religión". Ciencias

Sociales y Religión/Ciências Sociais e Religião, no 7: 203-209.

\section{Notas}

1 Entre as publicações que reúnem a produção do Grupo Catolicismo deste período e que foram organizadas por Pierre Sanchis, destaco aqui as três coletâneas: Catolicismo: modernidade e tradição; Catolicismo: cotidiano e movimentos e Catolicismo: unidade religiosa e pluralismo cultural, que saíram pela Editora Loyola (Sanchis 1992a, 1992b, 1992c). A essas coletâneas, acrescentaria Comunicações do ISER, no 45 (Sanchis 1994a), sobre sincretismo, e um texto, que considero da maior importância nos estudos do catolicismo no Brasil, intitulado "Uma identidade católica?", também publicado em Comunicações do ISER (Sanchis 1986).

2 Os trabalhos apresentados nessa mesa-redonda foram publicados na revista Ciencias Sociales y Religión/Ciências Sociais e Religião, da ACSRM, e encontram-se acessíveis na sua plataforma digital http:// seer.ufrgs.br/index.php/CienciasSociaiseReligiao.

3 Uma experiência que encontramos noutros antropólogos, como em Maurice Leenhardt, que Pierre cita, em sua conferência de abertura do evento de Belo Horizonte, para argumentar contra os excessos excludentes do conhecimento racional, apontando para a necessidade de articular mito e razão (Sanchis 2003a).

4 Permitam-me aqui fazer referência a um texto de Ari Pedro Oro (2018), em que assinala, na história das ciências sociais na França, a presença de um certo ethos coletivo de pesquisa e de produção científica, que teria iniciado com a Escola Sociológica Francesa ou escola durkheimiana, e que teve prosseguimento com um grupo de intelectuais: Henri Desroche, Emile Poulat, Jacques Maître, François-André Isambert e Gabriel Le Bras, que fundaram a revista Archives de Sciences Sociales des Religions (1956). Alguns desses intelectuais foram explicitamente citados por Pierre como seus mestres. 
Minha hipótese é que existiria uma correspondência entre esta experiência francesa e aquela que foi vivida no ISER, nos anos 1980-1990. E que Pierre teve um papel fundamental em imprimir esse ethos francês especialmente no Grupo de Estudos sobre Religião e na revista Religião $\mathcal{E}$ Sociedade.

5 Neste esforço reflexivo, Pierre procurava, sempre, distanciar-se do debate sobre a contaminação religiosa da produção científica da área dos estudos da religião no Brasil, que, nos anos 1990 e início dos 2000, ensejou múltiplas controvérsias e alinhamentos teóricos. Farei referência a dois textos, entre muitos, que demarcaram esse debate. O primeiro, de Antônio Flávio Pierucci, inaugura propriamente o debate (Pierucci 1997, 1999); o segundo, de Marcelo Camurça, em resposta ao texto de Pierucci (Camurça 2001).

${ }^{6}$ A apropriação de habitus por Pierre remete mais a Norbert Elias do que a Pierre Bourdieu e adverte o leitor de que seu uso estaria isento de qualquer ranço substantivista e determinista (Sanchis 2003a:29).

7 Ainda que não o cite explicitamente nos textos que utilizamos para elaborar este artigo, o conceito de "estrutura na conjuntura" de Marshall Sahlins caberia perfeitamente na análise de Pierre (Sahlins 1990).

8 Pierre toma esta expressão Identidades mortíferas de Amim Maaluf, um escritor de origem e nacionalidade libanesas e de cultura e nacionalidade também francesas (Sanchis 2003b:167).

9 Trata-se de uma pesquisa etnográfica de grande fôlego, realizada em Portugal, nos anos de 1970, da qual resultou o livro Arraial: Festa de um povo. As romarias portuguesas (1983). Marcado por uma forte influência do estruturalismo, revela-se aí uma busca incessante das raízes ibéricas do catolicismo enquanto uma das vertentes fundantes da cultura brasileira.

${ }^{10}$ Este é o título, como sabemos, que Pierre dará à sua conferência de abertura do evento em sua homenagem em 1999 (Sanchis 2003b:17-49).

Submetido em: 25/07/2018

Aceito em: 02/08/2018

Carlos Alberto Steil (steil.carlosalberto@gmail.com)

Professor do Programa de Pós-Graduação em Antropologia Social da Universidade Federal do Rio Grande do Sul (UFRGS), Porto Alegre, RS, Brasil; Pesquisador CNPq1, Brasil; Membro do Grupo Sobre Naturezas e do Núcleo de Estudos da Religião (NER), UFRGS. 


\section{Resumo:}

\section{Fidelidades criativas: Ciência, mística e amizade na trajetória de Pierre Sanchis}

O presente artigo traça alguns fios que teceram a trajetória intelectual de Pierre Sanchis (1928-2018), destacado antropólogo franco-brasileiro da área dos estudos da religião. Tomando como guia uma fala sua, ao final da homenagem que lhe foi feita na UFMG, por ocasião da outorga do título de professor emérito (1999), o artigo apresenta alguns paisagens que marcaram essa trajetória. O nascimento e a infância entre duas culturas, catalã e francesa, e a incidência desta dupla identidade sobre sua existência e seu pensamento. Sua migração para o Brasil, seu retorno à Europa para completar sua formação em antropologia e a volta ao Brasil. A família, os amigos, as instituições de pesquisa (o ISER e a ACSRM) e suas articulações entre afeto e conhecimento. A religião como vida e como tema de investigação científica. A antropologia como vocação e como ofício. A política como o gerenciamento de identidades múltiplas. $\mathrm{O}$ artigo conclui discorrendo sobre as dualidades e suas articulações: Brasil e religião, catolicismo e negritude, cultura e identidade.

Palavras-chave: Pierre Sanchis, Catolicismo, Cultura brasileira, Sincretismo, Identidade

\section{Abstract:}

Creative Fidelities: Science, affection and mysticism in the trajectory of Pierre Sanchis

The present article traces some threads that weave the intellectual trajectory of Pierre Sanchis (1928-2018), an outstanding Franco-Brazilian anthropologist from the studies of religion. Taking as a guide a speech of his, at the end of the homage that was made to him at UFMG, on the occasion of the granting of the title of professor emeritus (1999), the article presents some landscapes that have marked this trajectory. His birth and childhood between two cultures, Catalan and French, and the incidence of this dual identity on his existence and his thinking. His migration to Brazil, his return to Europe to complete his education in anthropology, and back to Brazil. Family, friends, research institutions (ISER and ACSRM) and their articulations between affection and knowledge. Religion as life and as a scientific research topic. Anthropology as a vocation and as a task. Politics as the management of multiple identities. The article concludes discoursing the dualities and their articulations: Brazil and religion, Catholicism and negritude, culture and identity.

Keywords: Pierre Sanchis, Catholicism, Brazilian culture, Syncretism, Identity 